\title{
THE IMPACT OF THE LUBRICATION STEP WITH MAGNESIUM STEARATE ON THE QUALITY TARGET PRODUCT PROFILE OF A MODIFIED RELEASE ORAL DOSAGE FORM CONTAINING A BCS CLASS II ACTIVE PHARMACEUTICAL INGREDIENT
}

\author{
PAUL ANCUDUMITRAȘCU ${ }^{1,2}$, CRISTINA GABRIELA STECOZA ${ }^{2,3}$, MARILENA GAVRILESCU $^{2}$, \\ CARMEN ALECSANDRESCU ${ }^{2}$, ALINA IVANCENCU $^{2}$, VALENTINA ANUȚA ${ }^{1 *}$, LACRĂMIOARA \\ POPA $^{1}$, MIHAELA VIOLETA GHICA ${ }^{1}$, CRISTINA ELENA DINU-PIRVUU ${ }^{1}$ \\ 1 "Carol Davila" University of Medicine and Pharmacy, Faculty of Pharmacy, Department of Physical and Colloidal \\ Chemistry, 6 Traian Vuia Street, 020956, Bucharest, Romania \\ ${ }^{2}$ Zentiva S.A., Portofolio Strategy and Investment Department, 50 Theodor Pallady Boulevard, 032266, Bucharest, Romania \\ 3 "Carol Davila" University of Medicine and Pharmacy, Faculty of Pharmacy, Center for Drug Sciences, 6 Traian Vuia \\ Street, 020956, Bucharest, Romania
}

*corresponding author: vali.anuta@yahoo.com

Manuscript received: December 2019

\begin{abstract}
Magnesium stearate is an excipient widely used in the pharmaceutical industry, due to its lubrication proprieties. The aim of the study is to evaluate the impact of the lubrication step with magnesium stearate on the Quality Target Product Profile of a modified release oral dosage form containing a BCS Class II active pharmaceutical ingredient and to determine the critical process parameters correlated to the lubrication step. In this context, experimental batches at industrial scale and pilot scale batches were manufactured with two different sorts of magnesium stearate in concentration of approximately $0.5 \%(w / w)$. Based on the experimental results, the over-lubrication phenomena was observed only during the manufacturing of batches with magnesium stearate with lower particle size distribution $(\sim 1 \mu \mathrm{m})$ and higher surface area. The over-lubrication had an higher impact on the physical parameters of the core tablets, such as resistance to crushing. Furthermore, the direct proportionality between the compressing settings and the resistance to crushing parameter was observed to be altered by the lubrication process. Due to the fact the over lubrication phenomena is dependent to the functional-related characteristics of magnesium stearate it can be concluded that the two magnesium stearate sorts cannot be interchangeable, for a tablet matrix with a majority plastic character during compression step.
\end{abstract}

\section{Rezumat}

Stearatul de magneziu este un excipient utilizat pe scară largă în industria farmaceutică, datorită proprietătilor de lubrifiere. Scopul studiului este de a determina influența procesului de lubrifiere cu stearat de magneziu asupra profilului de calitate al unui produs finit cu cedare modificată și administrare per os, care conține o substanță activă din clasa biofarmaceutică II si de a defini parametrii de proces corelați cu procesul de lubrifiere considerați critici. În această direcție, au fost procesate serii experimentale la scală industrială și serii pilot cu o concentrație de stearat de magneziu de aproximativ $0,5 \%(\mathrm{~m} / \mathrm{m})$. În urma rezultatelor obținute, fenomenul de supra-lubrifiere a fost observat doar pentru seriile procesate cu stearat de magneziu cu dimensiuni de particule mai mici $(\sim 1 \mu \mathrm{m})$ și cu o suprafață specifică mai mare. Procesul de supra-lubrifiere a influențat semnificativ parametrii fizici ale comprimatelor nucleu, precum rezistența mecanică. Proporționalitatea directă dintre setările echipamentului de comprimare și rezistența mecanică a fost redusă de procesul de lubrifiere. Din cauza faptului că procesul de lubrifiere este dependent de caracteristicile legate de functionalitate ale stearatului de magneziu, se poate concluziona că cele două tipuri de stearat de magneziu nu sunt interschimbabile, în cazul unei matrice cu componenți care prezintă caracter majoritar plastic în timpul etapei de comprimare.

Keywords: magnesium stearate, technological process, lubrication, quality target product profile, BCS Class II

\section{Introduction}

Magnesium stearate is widely used as a lubricant in the pharmaceutical industry at concentrations between 0.25 and $5.0 \%(w / w)$, due to reduction of the sticking phenomena and for the reduction of the ejection force during compression step [8, 17].
Magnesium stearate has a monograph in the European Pharmacopoeia [3], Japanese Pharmacopoeia [12] and United States Pharmacopoeia [16], and was selected by the Pharmacopeial Discussion Group for the harmonization of the mandatory section [8].

However, the European Pharmacopoeia monograph for magnesium stearate has a non-mandatory section describing the functionality-related characteristics (FRC) 
for this excipient, such as particle size distribution, specific surface area and thermogravimetric properties. These parameters are defined as characteristics that may be relevant when magnesium stearate is used as lubricant in tablets and capsules [3].

The importance of functionality-related characteristics (FRC) of magnesium stearate was assessed by the authors in a previous study [4]. The conclusion of the study was that its specific surface area and the particle size distribution can be defined as critical material attributes, with impact on the core tablets physical parameters, such as resistance to crushing. During the same study, it was concluded that the blending volume can be defined as a critical process parameter when the lubrication step is performed with magnesium stearate with a lower particle size and high specific surface area [4].

Although, the literature data mention a reduction of the in vitro dissolution rate after a higher lubrication time $[1,7,8,17]$ for the evaluated formulation the in vitro dissolution profile of the tablets was not impacted by the FRC of magnesium stearate 4]. The influence of the FRC on the physical parameters of the tablets is correlated with the hydrophobic effect, and it is more obvious for substances with plastic deformations during compression step, due to the fact that no new surfaces are formed. Substances with brittle behaviour during compression step are less influenced as new surfaces are created under the compression force [9, 11]. The Quality-by-Design (QbD) concept had been adopted in drug development as a viable strategy in order to ensure an adequate product quality through in depth process understanding [4]. Its usefulness led to this approach to also be extended to other areas, like bioanalytics [13].

The QdB based Quality Target Product Profile (QTTP) concept is the basis of design for the development of the product and it can include the administration route, the pharmaceutical form, the strength, the packaging form and the critical quality criteria of the product [6].

The evaluated formulation for this study is a low dose film-coated modified release oral dosage form containing felodipine, a BCS II active pharmaceutical ingredient (API). According to the Biopharmaceutical Classification System (BCS), a BCS Class II API is a substance with low solubility and low permeability [15]. In this context, the parameters defined as the critical quality criteria of the finished product that can be influenced by the over lubrication effect during the blending step with magnesium stearate were defined as the in vitro dissolution and the uniformity of content. Furthermore, based on the previous study results [4], physical parameters such as resistance to crushing and friability are proposed to be evaluated.

The scope of the study is to evaluate the impact of the lubrication step with magnesium stearate on the Quality Target Product Profile of a modified release oral dosage form containing a BCS Class II active pharmaceutical ingredient and to determine the critical process parameters for the lubrication step.

\section{Materials and Methods}

Two types of hydroxypropyl methylcellulose (HMPCs) with different viscosity grades $(4000 \mathrm{cP}$ and $100 \mathrm{cP}$ ) were used in the formulation. The functional role of HPMCs is to determine the extended release matrix and the dissolution rate of the active substance. Other excipients used in the formulation are lactose monohydrate (used as a filler in formulation and having brittle character during compression), cellulose microcrystalline (used as a filler), sodium lauryl sulfate (anionic surfactant and wetting agent) and magnesium stearate (used as the lubricant in the formulation). The majority of the excipients present in the formulation (the HPMCs and microcrystalline cellulose) have a plastic deformation characteristic under compression force.

The quality of the API and the excipients was evaluated according to the current in force monographs described in the European Pharmacopoeia.

In order to evaluate the impact of the lubrication step with magnesium stearate on the Quality Target Product Profile of a modified release oral dosage form containing a BCS Class II active pharmaceutical ingredient, experimental batches at industrial scale and pilot scale batches (1/10 of the industrial batch size) were manufactured with two different sorts of magnesium stearate in concentration of approximately $0.5 \%(w / w)$. Magnesium stearate A (MSA) have the particle size of approximately $1 \mu \mathrm{m}$, with a specific surface area of $20.5 \mathrm{~m}^{2} / \mathrm{g}$. Magnesium stearate B (MSB) have crystalline structure, various shapes and a particle size of approximately $50 \mu \mathrm{m}$ and a specific surface area of $1.4 \mathrm{~m}^{2} / \mathrm{g}$. The analytical methodology and the results are presented in the previous study [4].

The evaluated manufacturing process is a direct compression process - the API and the excipients are blend and the mixture is compress on a rotatory tableting machine. The coating step is performed for core tablets in a coating machine equipped with a fully perforated pan using an aqueous suspension of polymer, plasticizing agent and pigment.

Evaluation of resistance to crushing parameter for core tablets

The resistance to crushing of the core tablets was analysed according to EP 2.9.8 Resistance to crushing of tablets monograph [3], using ILR PH 21 equipment. The measurement was carried out on 20 core tablets. The results were expressed as mean, minimum and maximum values of the forces measured, in newton $(\mathrm{N})$. Evaluation of friability parameter for core tablets The friability of the core tablets was analysed according to EP 2.9.7 Friability of uncoated tablets monograph [3], using Erweka TAR 220 equipment. 
The measurement was conducted on a sample of whole tablets corresponding as near as possible to $6.5 \mathrm{~g}$. The acceptance criterion is that the maximum loss of mass (obtained from a single test or from the mean of 3 tests) is not greater than 1.0 per cent $(w / w)$.

Evaluation of in vitro dissolution profile of finished product

The dissolution profiles of the felodipine film-coated tablets were determined using a validated and discriminatory dissolution method using an USP Apparatus I (PharmaTest GmbH, Germany), according to an adapted method from the "Felodipine Extended-Release Tablets" monograph of the USP [16], using a $\mathrm{pH} 6.5$ phosphate buffer containing $1 \%$ sodium lauryl sulfate as dissolution medium [2]. The similarity of the dissolution profiles was assessed using the similarity factor $\left(f_{2}\right)$ or the, difference factor $\left(f_{1}\right)$, according to EMEA [5] and FDA [14] guidelines. An $\mathrm{f}_{2}$ value between 50 and 100 suggests that the two dissolution profiles are similar. The difference factor (f1) calculates the percent (\%) difference between the two curves at each time point and is a measurement of the relative error between the two curves. An $\mathrm{f}_{1}$ value between 0 and 50 suggests that the two dissolution profiles are similar. Evaluation of uniformity of content for compression blend

The determination of the uniformity of content for compression blend was performed on 10 pre-determined sampling points using a validated HPLC quantification method. The sampling point defined as critical points in the blending container based on risk assessment (for example, change in container geometry), and the acceptance criterion is that the RSD value for all ten individual values should be lower or at least equal with 5 .

Evaluation of loss on drying parameter for compression blend

The loss on drying is determined using a thermobalance set at $105^{\circ} \mathrm{C}$, using an approximately $3.5 \mathrm{~g}$ of compression blend. The result is calculated after a constant in weight is achieved.

Evaluation of bulk density, tapped density, Carr's index and Hausner ratio

Bulk density and tapped density were determined according to EP 2.9.34. Bulk density and tapped density of powders monograph [3].

The Carr's index and the Hausner ratio were determined according to EP 2.9.34. Bulk density and tapped density of powders monograph [3].

Data analysis

The statistical analyses as well as graphical representation of data were performed using the GraphPad Prism 7 (GraphPad Software Inc., La Jolla, CA, United States) software package. All data was analysed descriptively and expressed as total number, mean, range and variance. Dissolution data are reported as mean values of 6 replicates; the coefficient of variation $(\mathrm{CV} \%$; [mean value/standard deviation] $* 100 \%$ ) was calculated for each dissolution profile.

\section{Results and Discussion}

Evaluation of the impact of blending time with magnesium stearate on the critical quality attributes According to the results obtained during the previous study, the volume of the powder in the blending container can be defined as a critical parameter, due to the fact that during the blending stage with magnesium stearate MSA sort, when a lower blending volume was used, the over-lubrication phenomena was observed. In this context, parameters such as blending time, blending speed, feeder speed during compression stage, can also be defined as critical parameters, due to the fact that these parameters can influence the lubrication process [4].

The impact of the blending time over the critical quality attributes (such as in vitro dissolution and uniformity of content of the compression blend) and over the physical parameters of the core tablets (such as resistance to crushing and friability) was evaluated during manufacturing of two experimental batches at industrial scale using magnesium stearate MSB sort. The blending time with magnesium stearate for the first batch (EXP 01) was 5 minutes, and for the second batch (EXP 02) was approximately 3 times higher. The blending speed was constant for both batches, and the same blending equipment was used for the manufacturing of both industrial batches.

The individual results obtained for the uniformity of content for the compression blend are between $98 \%$ and $100 \%$ from the declared content, with a RSD value of $0.6 \%$, for EXP 01 and between $97 \%$ and $103 \%$ from the declared content with a RSD value of $1.6 \%$, for EXP 02 .

The results obtained for resistance to crushing and friability for the core tablets for EXP 01 and EXP 02 batches are presented in Table I.

Based on the results obtained for the similarity factor $\left(f_{2}=94\right)$ and for the difference factor $\left(f_{1}=1\right)$, it can be concluded that the in vitro dissolution profiles for EXP 01 and EXP 02 batches are similar. The dissolution profiles are represented in Figure 1.

The impact of functionality-related characteristics (FRC) of magnesium stearate on the compressibility of the compression blend and the compression behaviour

In order to evaluate the impact of functionality-related characteristics (FRC) of magnesium stearate on the compressibility of the compression blend and the compression behaviour, a pilot batch (PIL 01) and an experimental batch (EXP 03) were manufactured with magnesium stearate MSA sort. For the pilot batch, the occupied volume in the blending container is approximately $67 \%$ and for the experimental batch at industrial scale is approximately $33 \%$. 
Compression settings and results obtained for resistance to crushing and friability for core tablets for EXP 01 and

\begin{tabular}{|c|c|c|c|}
\hline \multicolumn{2}{|l|}{ 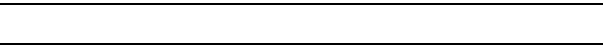 } & EXP 01 & EXP 02 \\
\hline \multicolumn{2}{|l|}{ Compression force, $\mathrm{kN}$} & 26.5 & 26.5 \\
\hline \multicolumn{2}{|c|}{ Pre-compression punches distance, $\mathbf{m m}$} & 2.8 & 2.8 \\
\hline \multicolumn{2}{|c|}{ Compression speed, tablets/hour } & 50000 & 50000 \\
\hline \multirow{3}{*}{ Resistance to crushing, $\mathrm{N}$} & Minimum & 50 & 51 \\
\hline & Maximum & 63 & 60 \\
\hline & Average value & 57 & 55 \\
\hline \multicolumn{2}{|l|}{ Friability, \% } & 0.2 & 0.2 \\
\hline
\end{tabular}

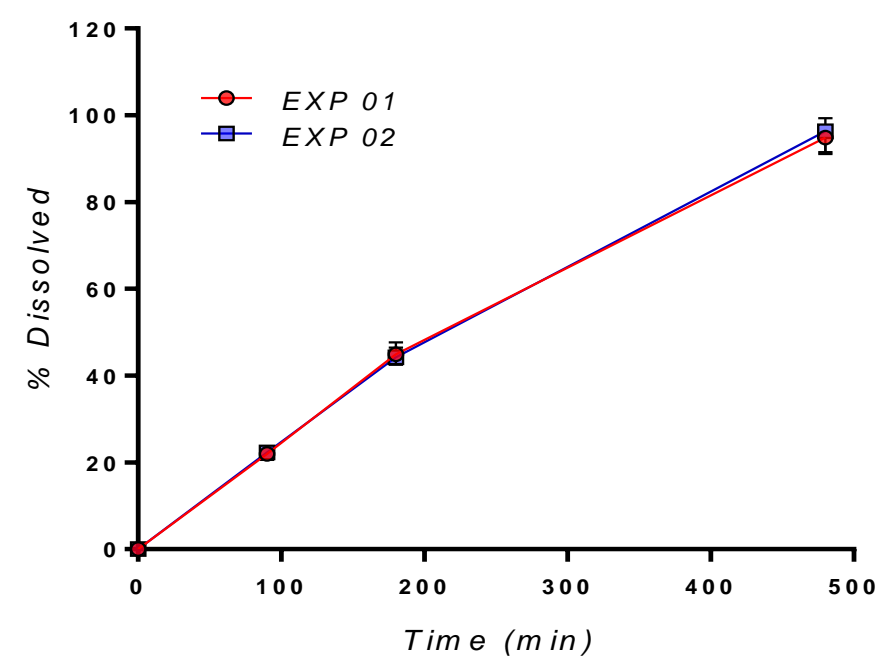

Figure 1.

In vitro dissolution profiles for batch EXP 01 and EXP 02

Based on the results obtained during the previous study, it was identified that the volume of the powder in the blending container can be defined as a critical parameter when the blending is performed using magnesium stearate MSA sort [3].

The physical parameters of the compression blend for PIL 01 and EXP 03 batches are described in Table II.
Based on the obtained results, it can be concluded that the lubrication step does not impact the loss on drying, the bulk density or the tapped density parameters of the compression blend. According to European Pharmacopoeia 2.9.36. Powder flow chapter, the results obtained for Hausner ratio and Carr's index indicates that the compression blends for PIL 01 and EXP 03 batches have fair flow character.

Table II

Results obtained for physical parameters for the compression blend for PIL 1 and EXP 03

\begin{tabular}{|l|c|c|}
\hline \multicolumn{1}{|c|}{ Compression blend } & PIL 01 & EXP 03 \\
\hline Loss on drying, \% & 1.63 & 1.60 \\
\hline Bulk density, g/mL & 0.45 & 0.45 \\
\hline Tapped density, g/mL & 0.56 & 0.55 \\
\hline Compressibility index (Carr's index) & 19.6 & 18.1 \\
\hline Cohesively index (Hausner ratio) & 1.24 & 1.22 \\
\hline
\end{tabular}

The compression settings and the results obtained for the resistance to crushing and friability obtained for core tablets during the manufacturing of PIL 01 and EXP 03 batches are presented in Table III.

An increase of compression force with $6.5 \mathrm{kN}$ and a decrease of the distance between the punches for precompression step with $1.1 \mathrm{~mm}$ in order to increase the pre-compression force were needed during the manufacturing of the experimental batch in order to obtained similar average value for resistance to crushing parameter.
Based on the obtained results, it can be concluded that for the pilot batch a proportionality between the compressing settings (by increasing the compression force and by reducing the distance between the punches for pre-compression step) and the increasing of resistance to crushing parameter is observed. For the experimental batch at industrial scale the proportionality is diminished and also a decreasing of powder compressibility was observed, when compared to the results obtained for the pilot batch. 
Table III

Compression settings and the results obtained for resistance to crushing and friability for core tablets for PIL 01 and EXP 03 batches

\begin{tabular}{|l|l|c|c|c|c|c|c|c|}
\hline \multicolumn{2}{|c|}{ Compression settings } & \multicolumn{3}{c|}{ E1 } & \multicolumn{5}{c|}{ EXP 03 } \\
\hline Compression force, kN & 13 & 16.5 & 16.5 & 16.5 & 17 & 20 & 23 \\
\hline Pre-compression punches distance, mm & 3.0 & 3.0 & 2.5 & 3.0 & 2.5 & 2.0 & 1.9 \\
\hline Compression speed, tablets/hour & 70000 & 70000 & 70000 & 70000 & 50000 & 50000 & 70000 \\
\hline \multirow{3}{*}{ Resistance to crushing, N } & Minimum & 44 & 47 & 49 & 35 & 36 & 44 & 43 \\
\cline { 2 - 10 } & Maximum & 54 & 53 & 58 & 47 & 45 & 50 & 55 \\
\cline { 2 - 9 } & Average value & 48 & 50 & 54 & 38 & 41 & 48 & 50 \\
\hline
\end{tabular}

The results obtained for the uniformity of content for compression blend are compliant with the predefined acceptance criteria. The differences observed for the RSD values for EXP 01 and EXP 02 batches $(0.6 \%$ versus $1.6 \%$ ) can be correlated with the technological variability and/or analytical variability and not with the difference in blending time with magnesium stearate. Based on the experimental results obtained for EXP 01 and EXP 02 batches, it can be concluded that the blending time with magnesium stearate MSB sort does not influence the physical parameters of the core tablets. Although the decreasing of the dissolution due to the over-lubrication phenomena caused by a higher concentration of magnesium stearate or by a higher mixing time were reported in the literature for immediate release tablets containing highly soluble drugs part of the BCS class III (such as ranitidine hydrochloride [17] or metformin hydrochloride [10]), the results obtained for the similarity factor $\left(\mathrm{f}_{2}\right)$ and the difference factor $\left(f_{1}\right)$ indicates that the blending time with magnesium stearate MSB sort does not impact the in vitro dissolution profile.

For this type of formulation, the blending time with magnesium stearate MSB sort with lower specific surface and higher particle size does not impact the critical quality attributes of the finished product, due to the fact the over lubrication phenomena didn't occur when the blending time was increased. Based on the data previously measured [4], the differences in the impact of blending time with magnesium stearate on the physical proprieties of the core tablets can be correlated to the difference in functionality-related characteristics of the magnesium stearate MSA and MSB sorts.

\section{Conclusions}

Although the over lubrication phenomena does not impact the physical parameters of the compression powder, such as bulk density, tapped density, Carr index (compressibility index) and Hausner index, the direct proportionality between the compressing settings (by increasing the compression force and by reducing the distance between the punches for pre-compression step) and the resistance to crushing parameter is altered by the lubrication process.
In this context, process parameters such as blending time, blending speed and feeding speed during compression step can be defined as critical for a tablet matrix with a majority plastic character only when the blending is performed with magnesium stearate with lower particle size and higher specific surface.

Due to the fact the over lubrication phenomena is dependent on the functional-related characteristics of magnesium stearate, it can be concluded that the two magnesium stearate sorts cannot be interchangeable, for a tablet matrix with a majority plastic character during compression step.

\section{Acknowledgement}

This paper was financially supported by "Carol Davila" University of Medicine and Pharmacy through Contract no. 23PFE/17.10.2018 funded by the Ministry of Research and Innovation within PNCDI III, Program 1 Development of the National RD system, Subprogram 1.2 - Institutional Performance - RDI excellence funding projects.

\section{Conflict of interest}

The authors declare no conflict of interest.

\section{References}

1. Abe H, Otsuka M, Effects of lubricant-mixing time on prolongation of dissolution time and its prediction by measuring near infrared spectra from tablets. Drug Dev Ind Pharm., 2012; 38(4): 412-419.

2. Burcea Dragomiroiu GTA, Popa DE, Velescu BS, Andrieș A, Ordeanu V, Nicolae AC, Drăgoi CM, Bârcă $\mathrm{M}$, Ginghină $\mathrm{O}$, Synthesis, characterization and microbiological activity evaluation of novel hard gelatine capsules with cefaclor and piroxicam. Farmacia, 2016; 64(6): 887-895.

3. Council of Europe. European Pharmacopoeia, $8^{\text {th }}$ edition. Council of Europe, Strasbourg, France, 2014.

4. Dumitrascu PA, Stecoza CG, Gavrilescu M, Ivancencu A, Anuta V, Ghica MV, Popa L, Pirvu-Dinu CE, The Influence of the Functionality-Related Characteristics of Magnesium Stearate on the Quality of Modified Release Oral Dosage Forms Containing a Biopharmaceutical Class II Active Substance. Proceedings of the Romanian National Congress of Pharmacy, $17^{\text {th }}$ Edition: $21^{\text {st }}$ Century Pharmacy - between Intelligent Specialization and Social Responsibility, Filodiritto Publisher, Bologna, Italy, 2018: 75-80. 
5. European Medicines Agency. Guideline on the Investigation of Bioequivalence, CPMP/EWP/QWP/ 401/98, 2010, www.ema.europa.eu.

6. European Medicines Agency. ICH Topic Q 8 (R2) Pharmaceutical Development Note for guidance on Pharmaceutical Development, EMEA/CHMP/167068/ 2004, 2009, www.ema.europa.eu.

7. Narang A, Badawy S, Handbook of Pharmaceutical Wet Granulation: Theory and Practice in a Quality Paradigm. Academic Press, Cambridge, USA, 2019: 300-301

8. Rowe R, Sheskey P, Quinn M. Handbook of Pharmaceutical Excipients, $6^{\text {th }}$ edition. Pharmaceutical Press, London, UK, 2009.

9. Swarbrick J, Encyclopedia of Pharmaceutical Science and Technology, Vol. V, CRC Press, Boca Raton, USA, 2013: 3531-3534.

10. Shadangi M, Seth S, Senapati D, Critical roles play of magnesium stearate in formulation development of a highly soluble drug metformin hydrochloride. IJPSR, 2012; 3(4): 1188-1193.

11. Takeuchi H, Nagira S, Aikawa M, Yamamoto H, Kawashima Y, Effect of lubrication on the compaction properties of pharmaceutical excipients as measured by die wall pressure. J Drug Deliv Sci Technol., 2005; 15(2): 177-182.

12. The Ministry of Health, Labor and Welfare. Magnesium stearate monograph. In Japanese Pharmacopeia, XVII $^{\text {th }}$ edition, 2016: 1188-1189.
13. Tuchilă C, Baconi D, Anuța V, Dinu-Pîrvu CE, Vlasceanu AM, Bălălău C, Constantin MM, Stan M, Development of a high performance chromatographic method for therapeutic drug monitoring of carbamazepine based on an experimental design approach. Farmacia, 2018, 66(3): 452-462.

14. U.S. Department of Health and Human Services, Food and Drug Administration, Center for Drug Evaluation and Research (CDER). Guidance for Industry Dissolution Testing of Immediate Release Solid Oral Dosage Forms, 1997, www.fda.gov.

15. U.S. Department of Health and Human Services, Food and Drug Administration, Center for Drug Evaluation and Research (CDER). Waiver of In Vivo Bioavailability and Bioequivalence Studies for Immediate-Release Solid Oral Dosage Forms Based on a Biopharmaceutics Classification System Guidance for Industry, 2017, www.fda.gov.

16. United States Pharmacopeial Convention. United States Pharmacopeia and National Formulary (USP 41-NF 36), 2016.

17. Uzunović A, Vranic E, Effect of magnesium stearate concentration on dissolution properties of Ranitidine Hydrochloride coated tablets. Bosn J Basic Med Sci., 2007; 7(3): 279-283. 